\title{
Involvement and emancipation of the worker. Action research in a university hospital
}

\author{
Ivan Bolis*, Claudio Brunoro and Laerte Idal Sznelwar \\ Production Engineering department, Universidade de São Paulo, Av. Prof. Almeida Prado, Travessa 2, $N^{o} 128$, \\ São Paulo, Brazil.
}

\begin{abstract}
The present action research article is linked to an ergonomics project in a university hospital. The author's proposal is to focus action on the effective worker involvement required for the creation of spaces / mechanisms within organizations where people can enhance cooperation and deliberation on matters relating to work. For this purpose, a committee was introduced to assist in finding problems and solutions directly in work situations, so that workers could experience relative autonomy allowing them to develop procedures and choose tools appropriate to their own real needs. Based on this organizational implementation and on subsequent interviews, the practical results are analyzed and related to employee involvement. One can conclude that workers in all areas of the organization can be active elements for improving working conditions and productivity in companies.
\end{abstract}

Keywords: ergonomics committee, emancipation, macroergonomics

\section{Introduction}

In recent years, major evolution has been seen in the importance attributed to an active, and even proactive, role on the part of the worker. We are currently in the midst of a period in history in which knowledge is considered to be the only resource able to create a continuous competitive advantage [14], and in the knowledge society, investing in human talent and its capacities is an important competitive factor [18].

The current vision is in the process of evolving, and the employee is no longer considered a productive resource on par with the machinery needed to assure stability and an optimum yield of preestablished tasks. Rather, the employee is becoming increasingly influential in companies' success [17]. Worker participation, even with some limitations [40], takes on a fundamental importance, be it as a motivational aspect for employees $[6,22,30]$, be it as an element that provides a competitive advantage for the company through their knowledge, with the creation of organizational knowledge being a participative process [18].
Based on these premises, one could question whether the current one is the most adequate for the management of people or the management of performance in organizations. Using a specific ergonomic-type study, the objectives of the present article are to assess perspectives in order to create a dynamic of improvement that has the involvement of people as one of its central aspects, and, above all, to analyze this type of positioning as an opening on the part of organizations that allows workers to develop professionally, to construct their health, and, ultimately, to blaze a trail toward their own emancipation.

\section{Theoretical standard}

The management of people has been greatly influenced by the change in paradigms in the organization of labor over the past several decades. The relationship between workers and work changed as a result of changes in the context in which they act. In such a context, worker emancipation may be considered as a means for people to free themselves from the oppres-

*Corresponding author. E-mail: bolis.ivan@yahoo.it. 
sion of work, to improve the performance of the organization, or even to re-appropriate their own work.

\subsection{Organizations: the evolution of the role of the worker in their strategies}

Innovation in the organization of work has taken place since the beginning of the industrial period in the perfecting of organizational solutions in order to maximize the utilization of the organization's own resources, including human resources, to achieve greater output and advantageous market conditions.

It was in this sense that the move from artisanship to the factory, through the concepts of specialization of tasks and standardization of product components, decreed the beginning of a change in vision, in which all forms of input became resources to be maximized [5]. Particularly with Taylorism, there was a clear attempt at separation between "those who think" (and manage work) and "those who execute" the work [1]. Worker participation was nil in the sense of the conception and organization of work: laborers, during this time, went so far as to become productive resources, de-appropriated from their know-how and unable to give their original contribution to and, as such, becoming alienated from, work [29].

Economic stimuli through rewards, which began to lose their effect on workers, the acknowledgement of the presence of the affectivity and responsibility of the work done by informal groups, and the recognition of the fact that productivity is closely linked to satisfaction in the workplace, formed the foundation for the birth, in the late 1920 s, of the School of $\mathrm{Hu}-$ man Relations [34]. In this school of thought, man cannot be considered simply as a work force and be forced to carry out tasks without an awareness of their purpose, but rather needs to be regarded taking his human nature into account. Even while beginning to understand the potential of worker participation, the School of Human Relations attached great importance to the perception and to the "humanity" of workers in achieving an increase in productivity. In other words, it professed that workers should participate in the decisions that lead to the tasks they execute [34].

Beginning in the 1950s, competitive pressure, the crisis in mass production, and the particular situation of Japan fostered the introduction of new theories. As explained by Krafcik [25], with Toyota it was possible to add the theories of Scientific Management to the application of work groups to increase productivity even further, transforming people into "multifunc- tional workers [9]." In this phase, the idea that men are a resource did not change. The difference for Taylorism is that, in addition to their physical strength, workers' intellectual capacities and ideas are taken advantage of as well [9].

The same period saw the emergence of the sociotechnical system organizational theory in response to an economic context of growing dynamicity and a greater interest in companies' social side. In order to optimize the system itself and increase productivity as well, new principles of work organization were proposed. Workers became a complement to machinery, and not mere extensions of it [2]. It is based on the perspective of the socio-technical school that workers begin to play a very important active role in the success of organizations.

Finally, among the main organizational theories being analyzed, Knowledge Management (KM) came about due to the fact that competitiveness, a turbulent outlook and innovation lead one to see knowledge as a resource (intellectual capital) to be managed as are economic resources, people and raw materials [2]. The objective of companies is to become "learning organizations" - in other words, organizations that acquire, create and efficiently transfer knowledge in an effective way inside the company, and alter their activities so as to reflect new knowledge and new expertise [20]. Workers gain importance in Knowledge Management, because their participation is fundamental [42], taking an active posture in the process of the construction of knowledge in the organization $[17,43]$.

From the side of organizations, changes in the direction of a wider participation of workers were directed, at every phase, toward a need to improve their performance. In general, depending on the type of business and their particular characteristics, the degree of worker participation is strictly dependent upon the performance workers are able to attain.

\subsection{Emancipation}

Emancipation refers to all actions that allow a person or group to access a state of autonomy through the cessation of dependence (of subjection) on any authority or power [39].

Despite the amplitude of the theme upon which this work is focused, the historical period in which emancipation became a well-defined theme (and not a simple work defining a period) was in the $19^{\text {th }}$ Century, corresponding to the development of economic activities resulting from the first industrial revolution 
(1780-1860). During this period, the theme of emancipation is closely related to alienation.

The term alienation was initially used from the philosophical point of view by Rousseau, Fichte, Schelling and, above all, by Hengel [23], but it was Karl Marx who questioned its causes and what social phenomena generated them, conducting an economic and political analysis in the works "Economic and Philosophic Manuscripts of 1844," "Foundations of the critique of political economy (1857-58)" and "The Capital." According to him, in bourgeois society, the laborer is alienated from the product of his own labor, from the activity itself, from humankind and from other men. In order to overcome alienation in work, Marx proposed the emancipation of the proletariat. For him, the only way possible to achieve emancipation is through revolution and the categorical imperative of eliminating relations in which the reality of men is one of enslavement and abandonment [23].

The theme of emancipation was very much used politically, linking it to revolution and to "leftist ideologies," but there is no lack of examples with different angles on the theme. According to Montgomery [33], for example, the participation of workers in politics allowed them to conquer power, just as in the United States, in the early $20^{\text {th }}$ Century, the process of democracy made the free market (capitalism) and the emancipation of work possible.

Another contribution to the discussion on the theme of emancipation with regards to work is made possible by the psychodynamics of work. Without wishing to delve into a detailed description, the psychodynamics of work was developed in the organizational context, having as the object of study the overcoming of psychic suffering caused by work and its capacity to wear out those afflicted by it, destabilizing their identity [12]. The psychodynamics of work thus proposes to study the space separating free behavior, which can allow the transformation of the reality surrounding the subjects in accordance with their desires and pleasures, and a pre-determined behavior outside the domain of these subjects. Basing itself on the ergonomic concepts of prescribed work and real work, it is in the distance between these two that the construction of identity in work either does or does not take place [11]. With reference to the interventions of psychodynamics, Lancman and Uchida affirm that they "[...] should lead workers to an active process of reflection on work itself, in order to allow for their appropriation and emancipation, and lead to a collective reconstruction of work [27, p. 88]." As introduced by Dejours [13], work can gen- erate the worst, including suicide, but can also generate the best, such as pleasure, self-fulfillment and emancipation.

Autonomy in work, as opposed to control through the prescription of very restrictive tasks, is an important question in the psychodynamics of work $[11,19]$ because it opens up space for subjects to deliberate on organization, allowing them to fulfill themselves in the internal environment of work [37]. In this perspective, and introducing two conceptions of emancipation (associated with the theme of autonomy), Perilleux [37] carries out an historic analysis all the way up to socio-technical theories, where he analyzes that autonomy became a means of regulation of flexible work and entrepreneurial demand. This was consequently translated into the need for greater responsibility on the part of the worker, creating in him an increase in insecurity. Examining, in this way, whether autonomy can still be a real ideal of emancipation in work, he concludes that autonomy can maintain all of its potential of emancipation if it is disconnected from the theme of individual responsibility.

In general, in the theories brought up thus far, the vision of emancipation is understood as the act of freeing oneself from something negative (in this case, alienation and a weaker social condition), but in the present study we wish to introduce the theme looking at emancipation as an action that permits a person or group to enter into a state of autonomy, proactiveness, freeing thought itself from the barriers present in organizations while at the same time responding to their objectives, without the presence of the responsibility of the individual.

Not much literature exists with the term "emancipation" used with this last meaning, much less alongside the theme of ergonomics. In a search of the available literature, some examples were found linked to the subjects of the work process in health [38], of organizational learning and information technology. Durant and Cashman [15] described how the fact of emancipating oneself, seeking to go beyond communicational limits in order to resolve problems, allows one to expand capacities and knowledge, and increase understanding among people, thus aiding in the construction of a community. Speaking about information technology, Klein and Myers [24] introduced emancipation as helping to "eliminate the causes of unwarranted alienation and domination and thereby enhance opportunities for realizing human potential $[24$, p. 69]."

In the article, the perspective of the emancipation of the subjects, as it exists in Maggi's proposals [28], 
was adopted. Acknowledging that workers have direct knowledge about their work, the best way to reduce constraint (i.e., when the organization removes a portion of individual autonomy in decision making) is to work towards the emancipation of workers, so they may have a greater influence on decisions about their work and the construction of their health.

\section{Methodology: semi-structured interview}

Based on an action-centered research project, the search for information on the theme in question was developed through interviews of the semi-structured type. According to Kvale [26], the interview is a conversation whose purpose and structure are defined by the interviewer and a professional interaction that goes beyond the spontaneous exchange of daily conversations after the acquisition of knowledge through listening and the formulation of attentive questions has been finalized. Various suggestions exist in literature as to how to carry out interviews. According to Creswell [10], the interview is made up of three phases: preparation of the interview, the effective construction of research questions and the implementation of interviews. The preparation of the interview is a very important stage that allows the interviewer to plan and construct it in order to align it with the initial objectives of the research in question. Creswell [10] discusses the importance of the selection of participants, who should be qualified at the end of the interview, but also willing to share information. In the second and third phases, various recommendations introduced by McNamara [31] were followed in the interview.

A script was developed in order to apply this methodology. The script is a sort of border within which the interviewee has the freedom of movement that allows him or her to treat all of the necessary matters at the end of research [8].

\section{Results}

\subsection{General presentation of the company}

The company that is the object of study is a Brazilian university hospital headquartered in São Paulo. A research project in the area of ergonomics has been under development at this institution since the year
2000. The main typologies of the actions developed there were the following three:

- Studies based on the Ergonomic Work Analysis (EWA) methodology [21] in specific work situations and places $[3,4,7,32,35,44]$.

- The development of a "training and capacitybuilding group- TCG" - in other words, a training course with the main objective of creating a team able, at a later stage, to multiply and diffuse concepts of ergonomics in the institution;

- The development of an Improvement Committee (IC) aimed at linking all ergonomics-type actions on a more strategic organizational level $[36,41]$.

The main results achieved are local improvements in some departments due to the EAT studies, the carrying out of reforms resulting from EAT studies developed within the TCG and achieved by way of the IC, the introduction of a computer system for the collection of epidemiological data to support managers' decisions, the development of some specific actions aimed at workers with special restrictions and needs, improvements in the material acquisition process and a raising of the awareness of the entire organization on such themes [36].

These actions obtained limited results, due mainly to the organizational context in which they were developed. In particular, management supported the carrying out of the research, but was unable to link it to the processes themselves, mainly with regards to strategic choices. With this, management was unable to provide the conditions to lend continuity to such actions. Citing several examples, not all of the EWA studies were implemented in the organization, the TCG had no effective continuation following the course period itself, the voluntary activities of activism in the theme were more occasional, because, among other reasons, all were very much involved in their own routines, and the IC has so far been unable to become truly effective.

The semi-structured interviews developed in this organization were introduced in the final phase of the project in question with the objective both of analyzing the degree of success of the ergonomic actions and to what degree the theme of ergonomics was disseminated in the hospital, and of understanding the relationship between the degree of participationemancipation of the worker and the success or lack thereof of specific ergonomic actions. In the article presented here, a selection of responses related to this last aspect will be introduced. 


\subsection{Selection of results derived from the semi- structured interview}

Various different interviews were developed at the university hospital, allowing for the collection of rather varied material. Five excerpts useful in the discussion of the themes presented in the present article are introduced below.

\subsubsection{Personal involvement of the participants of the Improvement Committee (IC)}

One question raised was related to the degree of involvement of the participants in the IC. For this question, the six people who participated most in the committee were interviewed. Among the various issues, the level of personal involvement, knowledge of the IC's specific objectives, future vision and an opinion regarding this particular organizational tool stood out. The level of personal involvement ended up proving proactive (indicating strong involvement) for two people, active (indicating involvement, but not very resourceful) for one, one of support (indicating an involvement resulting from specific requests) for two, and external (low level of involvement) for one. The most interesting pieces of data obtained were:

- Those who were clear about the IC's objectives had an exclusively supportive personal involvement.

- Those with a proactive personal involvement were familiar with the objectives and were the only ones with a negative future vision (aware that the IC had no strategic importance for the organization).

- There was unanimity among those familiar with the IC's real objectives: all of them had a positive evaluation of the Committee.

- The results achieved by the IC were acquired due to the determination of the participants with a proactive position. It is believed that, without these people, few, and perhaps no, results would have been obtained.

\subsubsection{Degree of voluntariness of the TCG participants}

Another interview analyzed the degree of voluntariness of the TCG's participants. For this question, all 19 of the individuals who participated in the group were interviewed. The participants were asked, among other issues, about the degree of voluntariness of participating in the initiative (if they were obliged to participate or not), how much their knowledge in ergonomic matters was widened, how much this knowledge was applied in actual work situations and what support was provided by the organization after the conclusion of the course. The most interesting pieces of data obtained were:

- The cases in which ergonomic knowledge was not applied in the area of origin were represented exclusively by those whose participation was conditioned by an invitation that could not be refused, or by those who affirmed they had not seen significant progress in their own knowledge in ergonomics-related subjects.

- The evaluation of the organization's support following the conclusion of the course (in which no participation whatsoever of these people was requested in successive proposals) is worse when the degree of initial voluntariness is better.

\subsubsection{Interview on the theme of ergonomics related to the purchasing process}

Another interview focused on aspects related to ergonomics and purchasing processes. For this issue, all of the university hospital's 46 managers were interviewed. The interviews centered on what actions were developed to consider ergonomic aspects (such as worker health) in the processes of the purchasing of goods, equipment and services in the institution. In this sense, each manager was questioned about personal care in such aspects when compiling purchase requisitions, if there was a need for outside help in order to consider worker health in purchase requests, or if there had ever been problems with the purchase of inadequate equipment. A list was also requested of the main difficulties encountered in including the worker health care aspect in purchase orders.

These interviews showed that 5 managers delegate purchase processes (and ergonomic aspects) to other people, 5 were not concerned with ergonomic aspects, 14 considered the technical aspect (adjustments to attend to and resolve the needs of service users) as a priority for the choice of material (or equipment), 16 considered both technical and ergonomic aspects, asking themselves if the material (or equipment) was adequate to employees' work, and, finally, 7 managers considered ergonomic aspects as priority, proactively seeking solutions, often original ones, to completely resolve health problems specific to work posts.

Relating these responses with others, the following relationships were surmised:

- Those who do not observe ergonomic aspects in purchasing processes in general have never had 
problems with inadequate purchases and did not need outside help to improve their purchases;

- Those managers presenting care (who are concerned with these aspects), on the other hand, have had inadequate purchases, which led them to become actively interested in the theme and to realize that it would be easier if this type of problem were resolved with outside help;

- Those interviewees with implicit care lie between the two previously described positions;

- Those with proactive care, in other words, who seek to anticipate and always incorporate these aspects and have never had problems, carefully and successfully choose their purchases, thus not requiring outside help.

Many problems were enumerated for managers to consider ergonomic aspects at the time of purchasing, the main ones of which were the lack of ergonomic knowledge, difficulty specifying tender procedures, delays in the purchasing process and the presence of other priorities at the hospital, the fact that prepurchase tests were not enough to make a wellstructured decision on the purchase, the economic limitations of expenditures and a Brazilian market suffering from a lack of solutions incorporating ergonomic aspects. In these responses, it was made clear how managers with proactive care did not present any personal difficulty; they continually seek knowledge, dedicate time to this issue, and take special care to ensure that technical specifications are as detailed as possible in order to purchase the most functional product from the technical point of view, and one that provides the best possible working conditions.

\subsubsection{The case of a manager who participated in the TCG}

There is an interesting case of a manager from an area connected to worker health who participated in the TCG. This manager voluntarily offered to introduce an ergonomic action in the work routine itself so that other areas of the hospital could receive suggestions regarding improvements for their own workers. This activity was of the additional type, and, as it was not formally supported by the institution, ended up corresponding to an increase in the work load. This ergonomic action was developed over the course of several months until, with the absence of support on the part of the institution fully understood, motivation was dampened and the service stopped being offered. Today, the person in question remains available to support and help to introduce improve- ments in the hospital, but exclusively in cases in which there is outside support (in other words, the person has lost his proactive posture).

\subsubsection{Interview with hospital service employees}

After a number of physical reforms carried out in the hospital following EWA studies, interviews were developed with the employees of one of the areas interested. A total of 14 people responded to nine questions on the changes in the physical structure and, in some cases, on processes. In response to a question on the importance of suggestions for improvements in the definition of a project for change in the work environment itself, it was confirmed that the workers recognize the fact that they are the ones most familiar with their own work and know what needs to be changed. In general, however, people prefer the accompaniment and responsibility of projects of change to remain with management, preferring themselves to develop a merely auxiliary and opinion-giving role.

\section{Discussion}

Discussions about the degree of involvement, the degree of voluntariness and the type of care taken were plentiful during the interviews, which allowed a great deal of data to be gathered regarding the theme of worker emancipation. It is pertinent, at this point, to make a specification: there exists a basic impossibility to define an emancipated subject, remaining within a functional organizational structure. In such cases, the subject may have a greater or lesser degree of emancipation, but his degree of freedom and autonomy can never be total. Based on this premise, it is not a matter of categorizing individuals as either emancipated or not, but rather with relation to their commitment, their greater degree of (albeit very incipient) voluntariness, the type of care, and their degree of proactive involvement in the direction of complete emancipation.

In general, on the path towards complete emancipation, the subject:

- Attains results with ergonomic criteria even without the help of a professional from outside the area. This was shown by cases found during the action research experience of one of the authors. One can obtain evidence on this affirmation in the posture of people with proactive involvement in the institution's IC. Without these key people, few changes would have taken place, 
no matter what was introduced by the researchers;

- Becomes more involved, is more familiar with the ergonomic actions and their objectives (such as in the case of those interviewed about the IC), has better performance in ergonomic actions (such as in the case of the interviews on the TCG with people who had learned and applied moderately - the concepts of ergonomics to a greater degree) and, as such, reduces the presence of false beliefs (such as the market and economic limitations presented in the interview with managers about purchases);

- Generally creates higher expectations regarding the results that ergonomics may achieve (such as in the case of the interviews about TCG);

- Is more sensitive to the degree of support from the institution (such as in the question of the future vision of the IC, in which the most emancipated - understanding that ergonomic actions did not have primary importance for decisionmakers in the organization - responded that they had a negative vision), and is, as such, more sensitive to failures and frustration when the expectations themselves are not attended to (such as in the case of the interviews about TCG, showing considerable lack of motivation in the assessment of support from the organization following the end of the course);

- Is more sensitive to the degree of involvement of other actors in the organization who are influential for the success of ergonomic actions (such as in the interviews on the IC in which the degree of involvement of the other participants and of the organization, which was low, resulted in a considerable loss of motivation).

Taking the results of the interviews with managers on purchase processes as a basis, there are other elements of discussion on the issue of emancipation that seldom appear among those persons with low and high degrees of emancipation and which appear at the two extremes with regards to degree of emancipation (as visually described in illustration 20, which does not have statistical foundations). These are:

- Knowledge of the existence of problems related to worker health. As was explained in the results of the interviews on purchases, this indicator is low in people with little emancipation, either because they do not have many problems in their own work situation or because they do not recognize them, and in highly emancipated people, because they resolve their problems as soon as they emerge. It is high in both situations because problems exist, are visible and need to be resolved by people with more knowledge.

- The need for help from an outside professional in solving problems. This indicator is closely linked to the previous one; recognizing the presence of problems in working conditions, this need diminishes the more the subject is proactive, thus managing to resolve them.

Some additional considerations that were brought up as well:

- People wish to become involved when they are able to see direct or indirect benefits for themselves. This means that well-developed communication is needed to show the results and the possible benefits to be achieved. At various points in the interviews, it was highlighted that information was often lacking, be it at the beginning of ergonomics projects (such as in the case of the TCG) or in their finalization (the same case of the TCG) and in the organization as a whole.

- The possibility of seeking emancipation does not depend on the worker's hierarchical level in the organization (in the TCG, for example, those with the highest degrees of voluntariness were from the operational area). Nevertheless, those truly achieving a greater degree of emancipation depend very closely on the degree of freedom received in the organization, which in these case of the University of São Paulo University Hospital increases with the hierarchical level (as was found in the TCG interview on the application of knowledge acquired in the TCG, the situation of those in the operational area is very strictly delimited, and they no longer offer to suggest improvements).

All of the considerations raised up to this point indicate how a proactive role of workers on various levels of the organization brings real benefits and results in ergonomic interventions (or interventions aimed at improvement in general). The proactive subjects have an interest in their health, in that of their workmates and their underlings (when they perform a supervisory role) and try to improve in accordance with the level of autonomy they have within the organization. These people do not sit and wait for the organization to create some sort of formal means of prevention or correction, but themselves become an active force that helps the organization take care of problems as quickly as possible. After all, the or- 
ganization is not a structure, but results from the dynamics of the subjects that constitute it.

\section{Conclusions}

The case study presents the results achieved through interviews developed after the specific application of an ergonomics study. Despite the limitations deriving from the fact that it is a study based on concepts developed in the discipline of ergonomics, the theory extracted by way of the discussion may be generalized and be valid in various different contexts.

The study was also developed in a university hospital, an institution with well-defined peculiarities, including that of acting in a geographically delineated area, having a well-cemented organizational structure, and having objectives that are not exclusively financial. This context originated the results presented in the article. It would be interesting to develop a similar study in a larger organization operating in a more open and global market and in a more competitive context. It is believed that the results achieved with this experience could be confirmed, and, in addition to this, elements could be found that would ultimately enrich the discussion. It would also be important to widen this type of research in the same institution in order to assist in the structuring of more perennial improvement devices that, at the end of the day, would be responsible for disseminating this type of practice and, above all, facilitating the actions carried out by the subjects.

\section{References}

[1] Antunes, R. Os sentidos do trabalho: Ensaio sobre a afirmação e a negação do trabalho. $6^{\text {a }}$ ed. São Paulo: Boitempo, 2003.

[2] Bartezzaghi, E. L'organizzazione dell'impresa. Processi, progetti, conoscenza, persone, Editore Etas, 2010.

[3] Benito, G. S.. Análise ergonômica do trabalho no serviço de higienização especializado do hospital universitário - USP. Trabalho de Conclusão de Curso - Escola Politécnica da USP, São Paulo, 2004.

[4] Bolis, I. Analisi ergonmica in ambiente ospedaliero. Studio del caso HU-USP. Trabalho de Conclusão de Curso - Politecnico di Milano, Milano, 2007.

[5] Bonazzi, G. I quattro principi alla base dell'Organizzazione Scientifica del Lavoro. In: Storia del pensiero organizzativo, Franco Angeli, p. 40-49, 2002.

[6] Casado, T. A motivação e o trabalho. In: FLEURY, M. T. L. (Org) As pessoas na organização. São Paulo: Gente, 2002.

[7] Cassano, G. R. Proposta de reestruturação do processo e do setor de montagem das refeições do SND do HU-USP. $133 \mathrm{p}$ Trabalho de Formatura - Escola Politécnica, Universidade de São Paulo, São Paulo, 2010.
[8] Corbetta, P. Metodologia e tecnica della ricerca sociale. Il Mulino, Bologna, 1999

[9] Coriat, B. Pensar pelo avesso. O modelo japonês de trabalho e organização. Rio de Janeiro: UFRJ/Revan, 1994.

[10]Creswell, J. W. Projeto de Pesquisa: métodos qualitativo, quantitativo e misto. Trad. Luciana de Oliveira da Rocha. $2^{\mathrm{a}}$ ed. Porto Alegre: Artmed, 2007.

[11]Dejours, C. A banalização da injustiça social. Trad. Luiz Alberto Monjardim. Rio de Janeiro: Fundação Getúlio Vargas, 3 ed., 2000.

[12]Dejours, C. Nouvelles formes de servitude et suicide. Travailler, 13, 53-73, 2005.

[13]Dejours, C. Entre o desespero e a esperança: como reencantar o trabalho? Cult [S.I.], vol. 139, p. 49-53, 2009.

[14]Drucker, P. Sociedade pós-capitalista. 6.ed., Pioneira, São Paulo, 1993.

[15]Durant, R.A.; Cashman, J.F. Theorizing limits: an exploration of boundaries, learning, and emancipation. Journal of Organizational Change Management, v. 16. n. 6, p. 650-665, 2003.

[16] Fischer. A. L., Um resgate conceitual e histórico dos modelos de gestão de pessoas. In: FLEURY, M. T. L. (Org) As Pessoas na organização, São Paulo: Gente, 2002.

[17]Fleury, M. T. L. A Gestão de Competência e Estratégia Organizacional. In: Fleury, M. T. L. (Org) As Pessoas na Organização. São Paulo: Gente, 2002.

[18]Fleury, M. T. L.; Oliveria JR. Aprendizagem e Gestão do Conhecimento. In: Fleury, M. T. L. (Org) As Pessoas na organização, São Paulo: Gente, 2002.

[19]Freitas, L. G. O processo de saúde e adoecimento dos professores que atuam em ambiente virtual. Em Mendes, A. M. (org) A psicodinâmica do Trabalho: teoria, método e pesquisas. São Paulo: Casa do Psicólogo, 2007.

[20] Garvin, D.A. Building a Learning Organization. In Harvard Business Review on Knowledge Management. Harvard Business School Press, pp. 47-80, 1998.

[21] Guérin, F; et al., Compreender o trabalho para transformá-lo: a prática da ergonomia. São Paulo: Edgard Blücher, 2001.

[22] Hertzberg, F.; Mausner, B.; Snyderman, B. B. The Motivation to Work (2nd ed.). New York: John Wiley \& Sons, 1959.

[23] Imbimbo, M.; Parasporo, L.; Salucci, M. Viaggio nella filosofia, vol. 3, Palumbo Editore, Palermo 2004.

[24]Klein Lein, H. K.; Myers, M. D. A set of principles for conducting and evaluating interpretive field studies in information systems. In: Management Information Systems Quarterly, vol. 23(1), p. 67-88, 1999.

[25]Krafcik, J. F. Triumph of the Lean Production System. In: Sloan Management Review, vol 30, n 1, p 41-52, 1988.

[26]Kvale, S. Doing Interviews: the Sage Quality Research Kit, The Cromwell Press Ltd., Trowbridge, 2007.

[27]Lancman S.; Uchida S. Trabalho e subjetividade: o olhar da Psicodinâmica do Trabalho. In: Cadernos de Psicologia Social do Trabalho, vol. 6, p. 79-90, 2003. http://www.revistasusp.sibi.usp.br/pdf/cpst/v6/v6a06.pdf

[28] Maggi, B. Do agir organizacional: um ponto de vista sobre o trabalho, o bem-estar, a aprendizagem. São Paulo: Edgard Blucher, 2006.

[29] Marx, Karl. Manuscritos econômico-filosóficos. São Paulo, Martin Claret, 2002.

[30] Maslow, A. Diário de negócios de Maslow. São Paulo, Qualitymark, 2003.

[31] McNamara, C. General guidelines for conducting interviews. Disponível em: http://managementhelp.org/evaluatn/intrview.htm. Acesso em: 27 outubro 2010.

[32] Mitsuishi, E. T. Aplicação de critérios ergonômicos para aquisição de equipamentos - estudo de caso do Hospital 
Universitário da USP. 109 p. Trabalho de Conclusão de Curso - Escola Politécnica da USP, São Paulo, 2009.

[33] Montgomery, D. Citizen Worker: The Experience of Workers in the United States with Democracy and the Free Market during the Nineteenth Century. New York: Cambridge UP, 1993.

[34] Motta, F. P.; Vascolncelos, I. Teoria Geral da Administração. São Paulo: Thomson Pioneira, 2002

[35] Nakahara, D. Análise ergonômica do trabalho de distribuição de refeições no HU-USP. 132 p. Trabalho de Formatura Escola Politécnica, Universidade de São Paulo, São Paulo, 2008.

[36] Neiva, A. G., Bolis, I., Snelwar, L. I. Um comitê de melhorias de condiçoes de trabalho numa instituição publica de saude In: XVI Congresso Brasileiro de Ergonomia, ABERGO 2010, Rio de Janeiro, 2010.

[37] Périlleux T. L'autonomie est-elle encore un idéal d'émancipation dans le travail?, in Travailler. Revue Internationale de Psychopathologie et de Psychodynamique du Travail, $\mathrm{n}^{\circ} 1$, p. 17-39, 1998 .

[38]Pires, M. R. G. M. Politicidade do cuidado e processo de trabalho em saúde : conhecer para cuidar melhor, cuidar para confrontar, cuidar para emancipar. In Ciência e saúde coletiva, vol. 10, n. 4, p. 1025-1035, 2005.

[39] Sabatini Coletti, Dizionario della lingua Italiana, Rizzoli Larousse, 2007.

[40] Smith, V. Worker participation: current research and future trends. Amsterdam: Elsevier, 2006.

[41] Snelwar, L. I.; Neiva, A. G. Relatório Final: Criação e Institucionalização do Comitê de Melhorias no Hospital Universitário. São Paulo: EPUSP. Departamento de Engenharia de Produção / FCAV. (relatório técnico), 2008.

[42] Theriou, G.N. and Chatzoglou, P.D. Enhancing performance through best HRM practices, organizational learning and knowledge management: A conceptual framework. In: European Business Review. V. 20, I.3, 2008.

[43] Thomke, S. and Reinertsen, D. Agile product development: managing development flexibility in uncertain environments. California Management Review, v. 41, n. 1, p. 8-30, Fall 1998.

[44] Wu M. J. Olhar, refletir, transformar - uma aprendizagem no HU - USP à partir do trabalho invisível da limpeza. Trabalho de Conclusão de Curso - Escola Politécnica da USP, São Paulo, 2002. 